\title{
IN VITRO CHARACTERIZATION OF GE NEGATIVE BOVINE HERPESVIRUS TYPES 1.1 (BHV-1.1) AND 1.2A (BHV-1.2A)
}

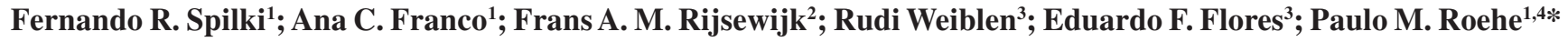 \\ ${ }^{1}$ Centro de Pesquisas Veterinárias Desidério Finamor, Eldorado do Sul, RS, Brasil; ${ }^{2}$ Institute for Animal Science and Health, \\ Division of infectious diseases and food chain quality, The Netherlands; ${ }^{3}$ Centro de Ciências Rurais, Universidade Federal \\ de Santa Maria, Santa Maria, RS, Brasil; ${ }^{4}$ Instituto de Ciências Básicas da Saúde, Universidade Federal do Rio Grande do Sul, \\ Porto Alegre, RS, Brasil.
}

Submitted: January 06, 2003; Approved: July 05, 2004

\begin{abstract}
This study aimed the in vitro growth characterization of a previously constructed Brazilian bovine herpesvirus 1.2a with a deletion in the glycoprotein $\mathrm{E}$ gene (BHV-1.2a $\mathrm{gE}$ ). The plaque sizes, penetration and growth kinetics of the Brazilian BHV-1.2a gE- were studied and compared with the parental virus, as well as with a BHV-1.1 gE' recombinant derived from an European BHV-1.1 strain. No statistical differences were observed between the $\mathrm{gE}^{-}$recombinants and the respective parental viruses penetration assays were performed. When single step growth curves were studied, no statistical differences were observed between $\mathrm{gE}^{-}$and parental viruses. However, it was observed that both $\mathrm{gE}^{-}$viruses were excreted from cells in significantly higher titres at 11 hours post infection in comparison with parental viruses. No statistical differences were observed when plaque sizes of parental viruses or $\mathrm{gE}^{-}$viruses we analyzed separately in each cell type. However, both $\mathrm{gE}^{-}$ recombinants displayed a significantly reduced plaque areas on three different cell cultures, in comparison with parental viruses, indicating that the lack of $\mathrm{gE}$ had the same effect on both BHV-1 subtypes, manifested by a restricted cell-to-cell spread in infected cells.
\end{abstract}

Key words: infectious bovine rhinotracheitis/infectious pustular vulvovaginitis, differential vaccine, in vitro growth characteristics, $\mathrm{gE}^{-}$recombinant, BHV-1.2a, bovine herpesviruses

\section{INTRODUCTION}

Bovine herpesvirus 1 (BHV-1), a major pathogen of cattle, is the agent of infectious bovine rhinotracheitis/infectious pustular vulvovaginitis virus (IBR/IPV). The virus is associated to a number of other clinical syndromes, including pustular balanopostitis, abortion, infertility and conjunctivitis (7). BHV1 strains can be subdivided into three distinct genotypes, BHV1.1, BHV-1.2a and BHV-1.2b (11). Genotypes 1.1 and 1.2a are related with a more severe disease, while genotype $1.2 \mathrm{~b}$ is less virulent (11).

The BHV-1 genome encodes several glycoproteins which are expressed on both the viral envelope and infected cell membranes. These glycoproteins participate in different functions, such as viral attachment and entry, cell-to-cell spread or host immune response evasion (14). The glycoprotein $\mathrm{E}$ (gE) gene is located in the unique short $\left(\mathrm{U}_{\mathrm{S}}\right)$ region of the BHV-1 genome, consisting of a $2300 \mathrm{bp}$ long fragment and encoding a glycoprotein of about 575 aminoacids (18). Although this glycoprotein is conserved among other members of the Herpesviridae, the role of $\mathrm{gE}$ in the in vitro growth characteristics may vary in function of the virus species and the host cell $(1,10)$. In herpes simplex virus type 1 (HSV-1) and varicella-zoster virus (VZV), gE can be found noncovalently linked to gI, forming an Fc binding site for immunoglobulins, which has been proposed as a mechanism to protect virus-infected cells from lysis by the

*Corresponding author. Mailing address: CPVDF, Caixa Postal 2076 - Eldorado do Sul. 90001-970, Porto Alegre, RS, Brasil. Telefax: (+5551) 481 3711. E-mail: proehe@adufrgs.ufrgs.br 
immune system (12). The gE complex in HSV-1 and VZV is also important in the cell-to-cell spread of the virus on different cell types $(1,3,4,5,10)$. In BHV-1.1, the Fc binding function of $\mathrm{gE}$ has not been demonstrated $(17,18)$. However, BHV-1.1 gE forms a complex with gI and is important for cell-to-cell spread $(2,15)$. In comparison to wild type viruses, $\mathrm{gE}$ negative ( $\left.\mathrm{gE}^{-}\right)$recombinants produce smaller plaque sizes in vitro, although the growth kinetics or penetration process of the virus seem not to be dependent on the presence of $\mathrm{gE}(2,13)$. In addition, $\mathrm{BHV}-1.1 \mathrm{gE}$ recombinants showed decreased virulence in experimentally inoculated $(2,8,15)$. Based on this reduced virulence, these recombinant viruses have been used in the development of vaccines against BHV-1 infections $(2,15)$.

A Brazilian $\mathrm{gE}^{-} \mathrm{BHV}-1.2 \mathrm{a}$ virus was previously constructed aiming the development of a vaccine strain (6). The proper in vitro and in vivo characterization of this virus will allow us to access its potential as a vaccinal virus. In the present study, the in vitro growth characteristics of the Brazilian $\mathrm{BHV}-1.2 \mathrm{agE}$ were studied and compared with the parental virus, as well as with a BHV-1.1 $\mathrm{gE}^{-}$recombinant, derived from an European BHV1.1 strain.

\section{MATERIALS AND METHODS}

\section{Cells and viruses}

The wild type BHV-1 strain SV265 (SV265 wt), was initially isolated from a calf with respiratory disease during an outbreak of infectious bovine rhinotracheitis (IBR) in São Borja, Rio Grande do Sul, Brazil. The virus was used for the construction of the BHV-1.2a $\mathrm{gE}$ negative virus $\left(265 \mathrm{gE}^{-}\right)$as described elsewhere (6).

The parental Lam strain (Lam wt), a BHV-1.1 strain, isolated from an animal with IBR in The Netherlands, and the Lam $\mathrm{gE}^{-}$ recombinant, were described previously (15). All viruses were multiplied in Madin Darby Bovine Kidney (MDBK), embryonic bovine trachea (Ebtr) or calf testis (CT) cells. Cell cultures were kept in Eagle's minimal essential medium (EMEM) supplemented with $5 \%$ to $10 \%$ fetal calf serum, $2 \mathrm{mM}$ glutamine and antibiotics (100 IU/ml penicillin and $100 \mathrm{mg} / \mathrm{ml}$ streptomycin). When appropriate, one percent low melting point agarose (Sigma) was added to EMEM to obtain the semi-solid medium.

\section{Plaque assays}

Confluent MDBK, Ebtr and CT monolayers prepared on 6 well plates were infected with 50 p.f.u. of the appropriate virus. After two hours of adsorption at $37^{\circ} \mathrm{C}$, the inoculum was removed and the cells overlaid with semi-solid medium. Four days post inoculation (p.i.) the cells were covered with fixative solution ( $10 \%$ formalin, $1 \%$ crystal violet) for at least 4 hours. The agarose was removed and monolayers dried at $37^{\circ} \mathrm{C}$ overnight. The diameter of at least 50 viral plaques was measured in each cell type.

\section{Penetration kinetics}

Penetration was assessed by allowing approximately 500 p.f.u. of the appropriate virus to adsorb on either MDBK or Ebtr monolayers for 1 hour at $37^{\circ} \mathrm{C}$. At different time intervals $(5,10,20,30,45,60$ and 120 minutes $)$ p.i., the inoculum was removed and the residual extracellular virus inactivated by a brief wash with a low $\mathrm{pH}$ buffer (1 M sodium citrate, $\mathrm{pH}$ 3.0). The cells were then overlaid with fresh semi-solid medium and incubated for four days. In a control experiment, additional cell monolayers were infected with 500 p.f.u. of all viruses, without low $\mathrm{pH}$ buffer treatment. Monolayers were then fixed with $10 \%$ formalin and viral plaques were counted at each time interval. The degree of penetration was calculated by comparison with the plaque count of the control experiment (set at $100 \%$ penetration). All tests were done in triplicate.

\section{Multiplication kinetics}

One step growth curves were assessed following infection of preformed MDBK cell monolayers at a m.o.i. of 10 . Adsorption was allowed for 1 hour at $37^{\circ} \mathrm{C}$ before the inoculum was removed and extracellular virus inactivated with $1 \mathrm{M}$ sodium citrate ( $\mathrm{pH} 3.0)$. The monolayers were then washed with fresh medium and incubated for different intervals $(3,5$, $7,9,11,13,16,24,36$ and 48 hours p.i.). After the incubation period, the supernatants were harvested and assayed for virus. All experiments were performed in triplicate. Virus titres were calculated according to the method of Spearmann and Kärber (9) and expressed as the $\log _{10}$ tissue culture infectious doses per $50 \mathrm{ml}\left(\mathrm{TCID}_{50} / 50 \mu \mathrm{l}\right)$.

\section{Statistical analysis}

Statistical analysis was performed using the Student $t$ test and the analysis of variance (ANOVA).

\section{RESULTS}

\section{Plaque Size}

The results of the plaque size analysis are shown in Table 1. The mean plaque areas formed by both $\mathrm{gE}^{-}$recombinants were strikingly reduced when compared to their respective parental viruses, in all three cell types. The reduction in virus plaque diameters was statistically significant for both $\mathrm{gE}^{-}$viruses on all three cell types $(\mathrm{p}<0.001)$. Both parental viruses produced similar plaque sizes in each cell type. In addition, mean plaque diameters obtained from both $\mathrm{gE}^{-}$recombinants in each cell type were very similar. The largest viral plaques were evident on CT cells, regardless of the virus strain under study $(\mathrm{p}<0.001)$. On the other hand, the smallest plaques were invariably found on MDBK cells $(p<0.001$; Table 1$)$. Fig. 1 shows the plaque morphology of both $\mathrm{gE}^{-}$recombinants and the respective parental viruses in all three cell types. 
Table 1. Plaque diameters of parental (SV265, Lam) and gE recombinants (265 $\left.\mathrm{gE}^{-}, \mathrm{Lam} \mathrm{gE}^{-}\right)$on three cell types (CT, Ebtr and MDBK).

\begin{tabular}{lccc}
\hline \multirow{2}{*}{ Virus } & \multicolumn{3}{c}{ Plaque diameter $(\mathbf{m m})^{a}$} \\
\cline { 2 - 4 } & CT & Ebtr & MDBK \\
\hline \multirow{2}{*}{ SV265 } & 0.25 & $(0.004)$ & 0.16 \\
& $(0.04)$ & 0.07 & $(0.04)$ \\
\multirow{2}{*}{$\mathbf{2 6 5} \mathbf{g E}^{-}$} & 0.13 & $(0.02)$ & 0,06 \\
& $(0.015)$ & 0.018 & $(0.006)$ \\
Lam & 0.26 & $(0.034)$ & 0.13 \\
& $(0.02)$ & 0.09 & $(0.03)$ \\
LamgE- & 0.15 & $(0.03)$ & 0.07 \\
& $(0.02)$ & 0.018 & $(0.008)$ \\
\hline
\end{tabular}

${ }^{a}$ Plaques were measured (average of 50 plaques/measure) 4 days after infection of cultures. Numbers in brackets refer to standard deviation.

a)
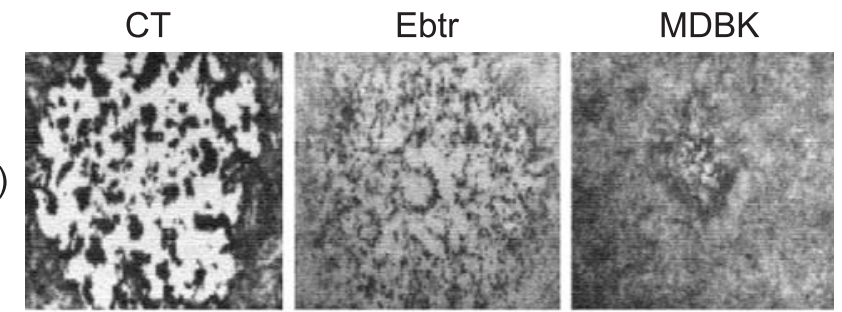

b)
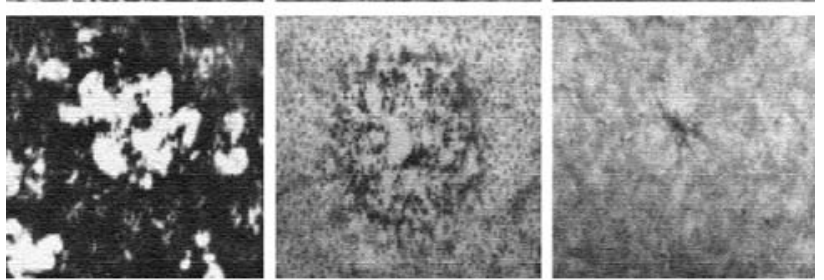

c)
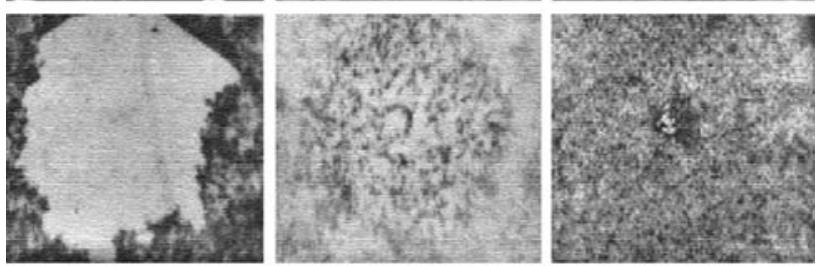

d)
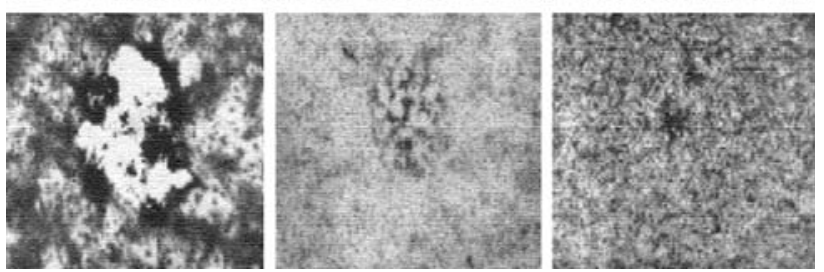

Figure 1. Plaque morphology of SV265 (a), $265 \mathrm{gE}^{-}$(b), Lam (c) and Lam gE- (d) produced on CT (column 1), Ebtr (column 2) and MDBK (column 3). Magnification 50X.

\section{Penetration kinetics}

Plaque production was first visualized after 20 minutes of adsorption on both MDBK and Ebtr cells by both $\mathrm{gE}^{-}$and wild type viruses (Fig. 2). An increase in penetration rates was observed from 45 minutes p.i. when the two $\mathrm{gE}^{-}$recombinants and parental viruses were analyzed on MDBK or Ebtr cultures. However, both Lam wt and Lam gE- showed a significantly larger number of viral plaques at 45 and 60 minutes p.i. when compared to SV265 wt and $265 \mathrm{gE}$. All four viruses produced the maximum number of plaques at about 120 minutes p.i. No significant differences were observed when $\mathrm{gE}^{-}$recombinants were compared to their respective parental viruses on both cell cultures.

\section{Multiplication kinetics}

The one step growth curves of SV265, $265 \mathrm{gE}$, Lam wt and Lam $\mathrm{gE}^{-}$are shown in Fig. 3. The multiplication kinetics of 265 $\mathrm{gE}^{-}$was undistinguishable from its parental strain. Similarly, no significant differences where found between the multiplication kinetics of Lam $\mathrm{gE}^{-}$and Lam wt. In all cases, viral progeny was first detected at 7 hours p.i. About 10 times more infectious

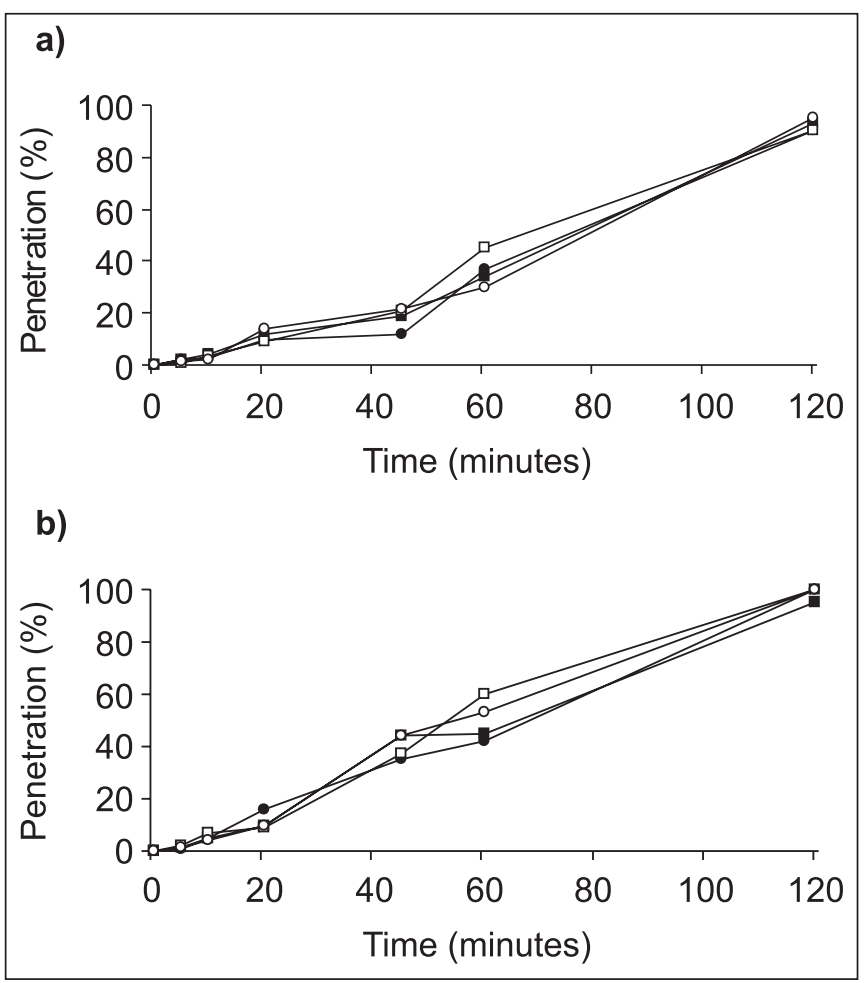

Figure 2. Penetration kinetics of SV265 wt, $265 \mathrm{gE}^{-}$(a), Lam wt and Lam gE- (b). Wild type viruses in MDBK and Ebtr are represented by: $(\mathbf{O})$ and $(\square)$, respectively. $\mathrm{gE}^{-}$viruses in MDBK and Ebtr are represented by: $(O)$ and $(\square)$, respectively. Time is expressed in minutes p.i. 


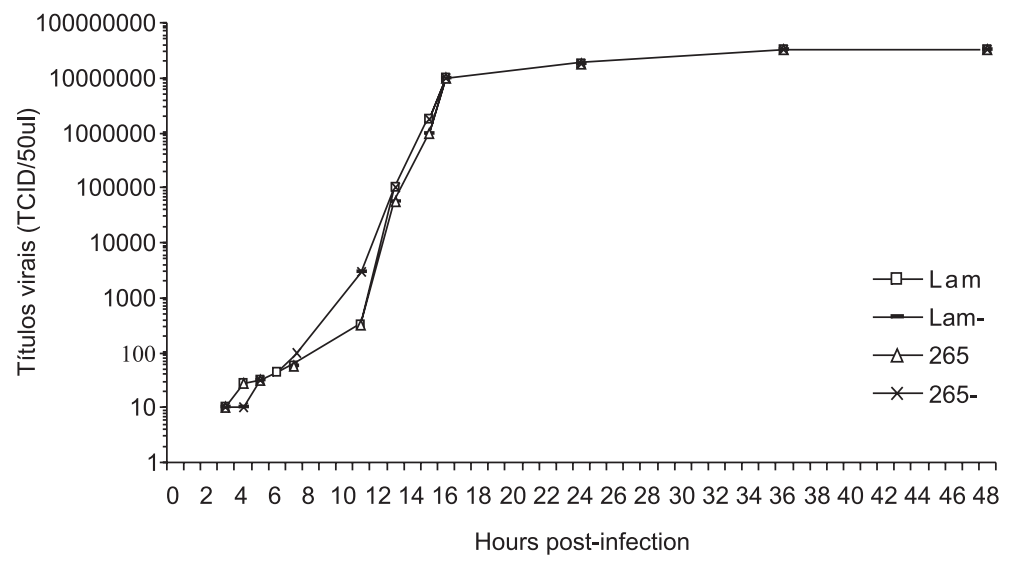

Figure 3. Growth kinetics of Lam wt $(\square), \operatorname{Lam~gE}^{-}(\times), \operatorname{SV} 265 \mathrm{wt}(\triangle)$ and $265 \mathrm{gE}^{-}(-)$in MDBK cells. Virus titres in TCID $50 / 50 \mu 1$, are expressed as the reciprocal of virus titres in $\log _{10}$.

virus was detected in the supernatants harvested from cells infected with $\mathrm{gE}^{-}$viruses than with parental viruses. However, all viruses reached maximum viral titres 36 hours p.i., when infectious titres for both $\mathrm{gE}^{-}$and wild type were very similar (between $10^{6}$ and $10^{7} \mathrm{TCID}_{50}$ ).

\section{DISCUSSION}

Glycoprotein E gene of alphaherpesviruses can be deleted from the viral genome with no major implications in viral replication. As the deletion of $\mathrm{gE}$ can be accompanied by a significant reduction in virulence, $(2,15,16)$, as part of a study to develop a vaccine against BHV-1 infections, it was intended to examine some in vitro properties of a Brazilian BHV-1.2a gE- In this study, the in vitro properties of two gErecombinants of BHV-1 (BHV-1.1 and BHV1.2a) and the respective parental viruses were examined.

In this study, the plaque sizes produced by gE- recombinants and their parental viruses were measured on Ebtr, MDBK and $\mathrm{CT}$ cells. There was a significant decrease in the mean diameters of viral plaques produced by both $\mathrm{gE}^{-}$recombinants, in comparison with their respective parental viruses, on all three cell types tested. The reduction in plaque size was at the order of 50 to $70 \%$, depending on the virus and cell type. In addition, both $\mathrm{gE}^{-}$recombinants showed similar reduction in plaque sizes on the three cell types analyzed. These results indicate that both $\mathrm{gE}$ negative viruses were severely impaired in direct cellto-cell spread, as already described for other $\mathrm{gE}^{-}$herpesviruses $(1,2,13)$.

To investigate the entry of the viruses into cells, two different cell types were used, Ebtr and MDBK. No statistically significant differences were observed between the penetration kinetics of parental and $\mathrm{gE}^{-}$recombinants, which indicates that $\mathrm{gE}$ does not play an important role in virion penetration of both BHV-1 subtypes.

To compare the multiplication efficiency of the $\mathrm{gE}^{-}$and parental viruses, virus production on cells infected at a high m.o.i. was evaluated. Although no significant differences were found in the final virus titres obtained, the $\mathrm{gE}-$ recombinants were released in higher titres from infected cells at 11 hours p.i. This effect might be due to the difficulty of $\mathrm{gE}^{-}$viruses to spread directly form cell to cell. Therefore, more virions might have the chance to reach the apical cell membrane, being released in higher titres at early stages of infection.

In conclusion, cell-to-cell spread was the most important in vitro property affected by the absence of $\mathrm{gE}$ in both BHV-1 subtypes. This in vitro growth characteristic is probably related to the in vivo viral pathogenicity, as herpesviruses which have an impaired cell-to-cell spread show a decreased virulence when inoculated in animals $(2,8,15)$. Experiments are in progress to access the in vivo pathogenicity of the Brazilian $\mathrm{BHV}-1.2 \mathrm{gE}-$ in order to examine its potential as a vaccine virus.

\section{ACKNOWLEDGEMENTS}

F.R.S is a CNPq MSc fellow. P.M.R. is a CNPq $1 \mathrm{C}$ research fellow. This work was supported by PRONEX, CNPq, FAPERGS and IRFA Biotecnologia Industrial Ltda.

\section{RESUMO}

\section{Caracterização in vitro de herpes vírus bovino tipos 1.1 (BHV-1.1) e 1.2a (BHV-1.2a) gE negativos}

O presente estudo teve como objetivo a caracterização das propriedades de crescimento in vitro de uma amostra brasileira de herpesvírus bovino tipo 1.2a que apresenta uma deleção no gene que codifica a glicoproteína E (BHV-1.2a gE'). Os tamanhos de placa, cinética de penetração e cinética de multiplicação do vírus BHV-1.2a gE- foram estudados e comparados com o vírus parental, bem como com um vírus BHV-1.1 gE- recombinante, o qual é derivado de uma amostra européia de BHV-1.1. Em termos de cinética de penetração, não foram observadas diferenças significativas quando comparados os vírus $\mathrm{gE}^{-} \mathrm{com}$ os parentais. A determinação da cinética de multiplicação não demonstrou diferenças significativas entre os quatro vírus estudados. Foi entretanto observado que 11 horas pós infecção os dois vírus $\mathrm{gE}^{-}$foram excretados das células em títulos significativamente maiores do que os vírus parentais. Não foram observadas diferenças significativas quando comparados os diâmetros de placas formadas pelos dois vírus parentais. Da mesma forma, os diâmetros de placas dos vírus $\mathrm{gE}^{-}$foram semelhantes nos 
três tipos celulares estudados. Entretanto, a comparação dos diâmetros de placas entre os vírus $\mathrm{gE}^{-} \mathrm{e}$ os parentais mostrou uma redução significativa das placas dos vírus $\mathrm{gE}^{-} \mathrm{em}$ todos os tipos celulares. Esta característica indica que a falta da gE teve o mesmo efeito em ambos os subtipos de BHV-1, representado por uma disseminação viral célula-célula reduzida.

Palavras-chave: rinotraqueíte infecciosa bovina/vulvovaginite pustular infecciosa; vacinas diferenciais; características de crescimento in vitro; BHV-1.2a, vírus gE negativos, herpesvírus bovinos

\section{REFERENCES}

1. Balan, P.; Davis-Poyter, N.; Bell, S.; Atkinson, H.; Browne, H.; Minson, T. An analysis of the in vitro and in vivo phenotypes of mutants of herpes simplex type 1 lacking glycoproteins $\mathrm{gG}, \mathrm{gE}, \mathrm{gI}$ or the putative gJ. J. Gen. Virol., 75:1245-1258, 1994.

2. Chowdhury, S.I; Ross, C.S.D.; Lee, B.J.; Hall, V.; Chu, S. Construction and characterization of a glycoprotein E gene deleted bovine herpesvirus type 1 (BHV-1) Recombinant Virus. Am. J. Vet. Res., 60:227-232, 1999.

3. Dingwell, K.S.; Brunetti, C.R.; Hendricks, R.L.; Tang, Q.; Tang, M.; Rainbow, A.J.; Johnson, D.C. Herpes simplex virus glycoproteins E and I facilitate cell-to-cell spread in vivo and across junctions of cultured cells. J. Virol., 68(2):834-45, 1994.

4. Dingwell, K.S.; Doering, L.C.; Johnson, D.C. Glycoproteins E and I facilitate neuron-to-neuron spread of herpes simplex virus. J. Virol., 69(11):7087-98, 1995.

5. Dingwell, K.S.; Johnson, D.C. The herpes simplex virus gE-gI complex facilitates cell-to-cell spread and binds to components of cell junctions. J. Virol., 72(11):8933-42, 1998.

6. Franco, A.C.; Rijsewijk, F.A.M.; Flores, E.F.; Weblen, R.; Roehe, P.M. Construction and characterization of a glycoprotein E deletion mutant of bovine herpesvirus type 1.2 strain isolated in Brazil. Braz. J. Microbiol., 33(3):274-278, 2001.
7. Gibbs, E.P.J.; Rweyemamu, M.M. Bovine herpesviruses. Part I. The Vet. Bull., 47:317-343, 1977.

8. Kaashoek, M.J.; Rijsewijk, F.A.; Ruuls, R.C.; Keil, G.M.; Thiry, E.; Pastoret, P.P.; Van Oirschot, J.T. Virulence, immunogenicity and reactivation of bovine herpesvirus 1 mutants with a deletion in the $\mathrm{gC}, \mathrm{gG}, \mathrm{gI}, \mathrm{gE}$, or in both the gI and gE gene. Vaccine; 16(8):802-9, 1998

9. Lorenz, R.J.; Bogel, K. Laboratory techniques in rabies: methods of calculation. World Health Organ., 23:321-35, 1973.

10. Mettenleiter, T.C.; Schreurs, C.; Zuckermann, F.; Ben-Porat, T. Role of pseudorabies virus glycoprotein $\mathrm{gI}$ in virus release from infected cells. J.Virol., 61(9):2764-9, 1987.

11. Metzler, A.E.; Matile, H.; Gassmann, U.; Engels, M.; Wyler, R. European isolates of bovine herpesvirus 1: a comparison of restriction endonuclease sites, polypeptides, and reactivity with monoclonal antibodies. Arch. Virol., 85:57-69, 1985.

12. Olson, J.K.; Grose, C. Endocytosis and recycling of varicella-zoster virus $\mathrm{Fc}$ receptor glycoprotein gE: internalization mediated by a YXXL motif in the cytoplasmic tail. J. Virol., 71(5):4042-54, 1997.

13. Rebordosa, X.; Pinol, J.; Perez-Pons, J.A.; Lloberas, J.; Naval, J.; Serra-Hartmann, X.; Espuna, E.; Querol, E. Glycoprotein E of bovine herpesvirus type 1 is involved in virus transmission by direct cell-tocell spread. Vir. Res., 45(1):59-68, 1996.

14. Spear, P.G.; Shieh, M.; Herold, B.C.; WuDunn, D.; Koshy, T.I. Heparan sulfate glycosaminoglycans as primary cell surface receptors for herpes simplex virus. Adv. Exp. Med. Biol., 313:341-53., 1992.

15. Van Engelenburg, F.A.C.; Kaashoek, M.J.; Rijsewijk, F.A.M.; Van den Burg L.; Moerman, A.; Gielkens, A.L.J.; Van Oirschot, J.T. A glycoprotein E deletion mutant of bovine herpesvirus 1 is avirulent in calves. J. Gen. Virol., 75:2311-2318, 1994.

16. Vannier, P.; Hutet, E.; Bourgueil, E.; Cariolet, R. Level of virulent virus excreted by infected pigs previously vaccinated with different glycoprotein deleted Aujeszky's disease vaccines. Vet. Microbiol., 29:213-223, 1991

17. Whitbeck, J.C.; Knapp, A.C.; Enquist, L.W.; Lawrence, W.C.; Bello, L.J. Synthesis, processing, and oligomerization of bovine herpesvirus $1 \mathrm{gE}$ and gI membrane proteins. J. Virol., 70:7878-84, 1996.

18. Yoshitake, N.; Xuan, X.; Otsuka, H. Identification and characterization of bovine herpesvirus-1 glycoproteins E and I. J. Gen. Virol., 78:1399-1403, 1997. 